Sistrom, W. R. (1960). J. gen. Microbiol. 22, 778-785

\title{
A Requirement for Sodium in the Growth of Rhodopseudomonas spheroides
}

\author{
BY W. R. SISTROM \\ The Biological Laboratories, Harvard University, Cambridge, Massachusetts, U.S.A.
}

It was shown by MacLeod and his co-workers that among bacteria only the true marine forms have a specific sodium requirement. These all require this ion in concentrations of the order of a few tenths of $1 \%$. The non-marine bacteria studied by MacLeod were distinguished from marine forms by their lack of any requirement for sodium (MacLeod, Onofrey \& Norris, 1954; MacLeod \& Onofrey, 1956). In view of these facts, the following observation, which I made in the course of studying the amino acid nutrition of Rhodopseudomonas spheroides, seemed significant. This bacterium can grow very well in media of ordinary ionic strength and thus is not obviously marine. I observed that it did not grow in a medium in which an artificial mixture of amino acids had replaced an acid hydrolysate of casein. Since almost $40 \%$ of the hydrolysate used was sodium chloride, I added a little $\mathrm{NaCl}$ to the medium containing the artificial mixture of amino acids. I then found that the growth was as rapid as in the medium made with casein hydrolysate. It was easily shown that a very much simpler mixture of amino acids permitted rapid growth in the presence of as little as $100 \mu \mathrm{g}$. NaCl $/ \mathrm{ml}$. This requirement for a low concentration of sodium seemed to set this organism apart both from marine and from terrestrial bacteria and thus to merit a more detailed analysis, the first results of which are reported here.

\section{METHODS}

Chemicals. All chemicals used were of reagent or analytical grade. The succinic acid was recrystallized from water.

Media. The media used were all modifications of one originally devised by Dr S. H. Hutner and which has already been described (Cohen-Bazire, Sistrom \& Stanier, 1957). The formulation and composition of the various modifications are set out in Tables 1 and 2.

General experimental procedures. Most of the experiments were performed with a green mutant (strain 2.4.1-Ga) of Rhodopseudomonas spheroides (Griffiths \& Stanier, 1956). All the strains used were obtained from Dr R. Y. Stanier. The cultures were maintained and inocula prepared by photosynthetic growth on medium A.

Two experimental procedures were used in determining growth requirements. In the first, cultures were grown in rectangular growth flasks, $40 \mathrm{~mm}$. wide $\times 150 \mathrm{~mm}$. high and $15 \mathrm{~mm}$. thick (in the direction of the light path). The flasks were fitted with aeration and sampling tubes. The cultures were aerated with appropriate gas mixtures throughout the experiment. 
Table 1. Formulation and composition of the media used

\begin{tabular}{|c|c|c|c|}
\hline \multirow[b]{2}{*}{ Stock solution } & \multicolumn{3}{|c|}{ Stock solution (ml./l.) } \\
\hline & Medium A & Medium B & Medium C \\
\hline Solution $C^{*}$ & 20 & - & - \\
\hline Solution $\mathbf{C}(-\mathbf{K})^{*}$ & - & 20 & 20 \\
\hline Potassium phosphate (pH 6.8; $\mathrm{M}$ ) & 20 & 一 & 一 \\
\hline tris.-HCl (pH 7.3; $\mathbf{M})$ & - & 45 & $\mathbf{8 \cdot 5}$ \\
\hline $\begin{array}{l}\text { tris.-Phosphate ( } \mathrm{M} \text { in phosphate; } \\
\text { pH 6.8) }\end{array}$ & 一 & 一 & $\mathbf{1} \cdot \mathbf{0}$ \\
\hline$\left(\mathrm{NH}_{4}\right)_{\mathbf{2}} \mathrm{HPO}_{4}(\mathrm{M})$ & 一 & $\mathbf{1 \cdot 0}$ & 一 \\
\hline$(\mathrm{NH})_{4} \mathrm{SO}_{4}, 10 \%(\mathrm{w} / \mathrm{v})$ & $\mathbf{5}$ & - & - \\
\hline Potassium succinate, $10 \% \dagger$ & $\mathbf{2 0}$ & - & - \\
\hline Ammonium succinate, $10 \% \dagger$ & 一 & 20 & - \\
\hline tris-Succinate, $10 \% \dagger$ & - & - & 20 \\
\hline L-Glutamic acid $5 \% \ddagger$ & 2 & 2 & $\mathbf{2}$ \\
\hline L-Aspartic acid, $2 \% \ddagger$ & $\mathbf{2}$ & $\mathbf{2}$ & 2 \\
\hline $\mathrm{NaCl}, 5 \%$ & 10 & 一 & - \\
\hline
\end{tabular}

* Solution $C$ and solution $C(-K)$. (g./.): nitrilotriacetic acid, $10 \cdot 0 ; \mathrm{MgSO}_{4} .7 \mathrm{H}_{2} \mathrm{O}, 29 \cdot 5$; $\mathrm{CaCl}_{2} .2 \mathrm{H}_{2} \mathrm{O}$, 3-335; (mg./I.): $\mathrm{FeSO}_{4} \cdot 7 \mathrm{H}_{2} \mathrm{O}, 99 \cdot 0 ;\left(\mathrm{NH}_{4}\right)_{6} \mathrm{Mo}_{7} \mathrm{O}_{24} \cdot 4 \mathrm{H}_{2} \mathrm{O}, 9 \cdot 25 ;$ nicotinic acid, 50.0 ; thiamine $\mathrm{HCl}, 25.0$; biotin, 0.5 . Trace elements solution $50.0 \mathrm{ml}$. (The trace element solution contains in $100 \mathrm{ml}$ : $\mathrm{ZnSO}_{4} \cdot 7 \mathrm{H}_{2} \mathrm{O}, 1.095 \mathrm{~g}$; ethylenediamine tetraacetic acid, $250 \mathrm{mg}$.; $\mathrm{FeSO}_{4} \cdot 7 \mathrm{H}_{2} \mathrm{O}, 500 \mathrm{mg}$.; $\mathrm{MnSO}_{4} \mathrm{H}_{2} \mathrm{O}, 154 \mathrm{mg}$.; $\mathrm{CuSO}_{4} .5 \mathrm{H}_{2} \mathrm{O}, 39 \cdot 2 \mathrm{mg}$.; $\mathrm{CO}\left(\mathrm{No}_{3}\right)_{2}$. $6 \mathrm{H}_{2} \mathrm{O}, 24 \cdot 8 \mathrm{mg}$.; $\mathrm{H}_{3} \mathrm{BO}_{4}, 11 \cdot 4 \mathrm{mg}$.). The $\mathrm{pH}$ is adjusted to 6.8-7.0 either with $\mathrm{KOH}$ for solution C, or with tris-(2-amino-2-hydroxymethylpropane-1:3 diol) for solution $\mathrm{C}(-\mathrm{K})$.

$\dagger$ The percentages given are for the free acid.

¥ Solution effected by the addition of a few drops of concentrated ammonium hydroxide; or, in medium $C$, the equivalent weights of the free amino acids were added to the complete medium.

Table 2. Ionic and elementary composition of media

\begin{tabular}{|c|c|c|c|}
\hline \multirow[b]{2}{*}{ Iron or element } & \multicolumn{3}{|c|}{ Concentration ( $\mu \mathrm{g} \cdot / \mathrm{ml})}$. \\
\hline & Medium A & Medium B & Medium C \\
\hline $\mathbf{K}^{+}$ & $\mathbf{2 , 8 7 0}$ & - & - \\
\hline $\mathrm{Na}^{+}$ & 200 & - & - \\
\hline $\mathbf{N H}_{4}{ }^{+}$ & 135 & 756 & - \\
\hline tris $^{+}$ & - & 6,050 & 6,050 \\
\hline $\mathbf{P}$ & 610 & 32 & 32 \\
\hline $\mathbf{S}$ & 220 & 78 & 78 \\
\hline
\end{tabular}

In the second procedure $15 \mathrm{ml}$. medium, previously inoculated, were placed in $16 \times 150 \mathrm{~mm}$. test tubes containing the supplements called for by the experiment. From time to time $2.5 \mathrm{ml}$. samples were removed for optical density measurements. The growth rates were calculated from the optical densities of three or four samples from each tube. This method is clearly not so precise and reproducible as the first, but it is adequate to detect large differences in growth rates. It was used when many different mixtures of salts in various concentrations were called for.

In both procedures the cultures were incubated at $\mathbf{3 4}^{\circ}$ in water baths provided with glass windows. A standard light intensity of 600 foot-candles 
measured at the entrance window, was used. The light source was a bank of incandescent lamps. Bacterial mass was estimated from the optical density at $680 \mathrm{~m} \mu$. With the photometric equipment used an optical density of $0 \cdot 1$ unit corresponded to a cell mass equivalent to $c .75 \mu \mathrm{g}$. dry weight $/ \mathrm{ml}$.

The specific growth rate constant, $\mu$, was calculated from the mass doubling time, $t_{\mathrm{D}}$, by use of the formula $\mu=\ln 2 / t_{\mathrm{D}}$, and is expressed in reciprocal hours.

\section{RESULTS}

\section{The sodium requirement}

Medium A did not support the growth of Rhodopseudomonas spheroides unless sodium chloride was added; this is shown clearly in Fig. 1. It can be seen that the addition of as little as $5 \mu \mathrm{g}$. $\mathrm{Na}^{+} / \mathrm{ml}$. (added as chloride) produced a dramatic increase in the growth rate; and that with $40 \mu \mathrm{g} . \mathrm{Na}^{+} / \mathrm{ml}$. the growth rate was almost maximal in this medium. It should be noted that medium $\mathbf{A}$, without added sodium, supports rapid and abundant growth of Escherichia coli and Pseudomonas fuorescens; and after supplementation with cystine (see Hutner, 1944) it supports the growth also of Rhodospirillum rubrum. However, I found that two other strains of $R$. spheroides $(2.4 .7$, and 2.4 .1 from which the mutant $\mathrm{Ga}$ was derived) and one strain of $R$. palustris (2.1.11) did require sodium for growth in medium $\mathbf{A}$.

A comparison of the effect of sodium sulphate and of sodium nitrate with that of sodium chloride substantiated the conclusion that the response illustrated in Fig. 1 was due to sodium ion. This is shown by curves $1-3$ of Fig. 2. The results of the second experiment shown in Fig. 2 (curves 4-6) show that the response was specific for sodium: neither lithium, rubidium, nor caesium had any effect.

Sodium is required for aerobic growth of Rhodopseudomonas spheroides also. Under aerobic conditions the specific growth rate constant in medium B with $5 \mu \mathrm{g}$. $\mathrm{Na}^{+} / \mathrm{ml}$. was approximately $0.1 \mathrm{hr} .^{-1}$; without added sodium it was $0.04 \mathrm{hr}^{-1}$. A detailed analysis of the sodium requirement under aerobic conditions has not been carried out.

\section{The potassium requirement}

The results of an experiment on the effect of the addition of $\mathrm{K}^{+}, \mathrm{Rb}^{+}, \mathrm{Li}^{+}$, or $\mathrm{Cs}^{+}$to a medium containing $\mathrm{Na}^{+}(50 \mu \mathrm{g} . / \mathrm{ml}$. $)$ are shown in Table 3 . It can be seen that, as was of course expected, $\mathbf{K}^{+}$is required for normal growth. The growth which occurred in absence of $\mathrm{K}^{+}$(line 1 , Table 3 ) was shown in other experiments to be arithmetic rather than exponential; therefore, a specific growth rate constant cannot be calculated. Escherichia coli grows arithmetically in the absence of $\mathrm{K}^{+}$(Roberts et al. 1957). It can also be seen from Table 3 that the potassium requirement was met completely by rubidium, at least for three or four generations. I do not know whether a culture can be maintained indefinitely with rubidium replacing potassium. Neither caesium or lithium replaced potassium. These results are similar to those of MacLeod with certain lactobacilli (MacLeod \& Snell, 1948). 


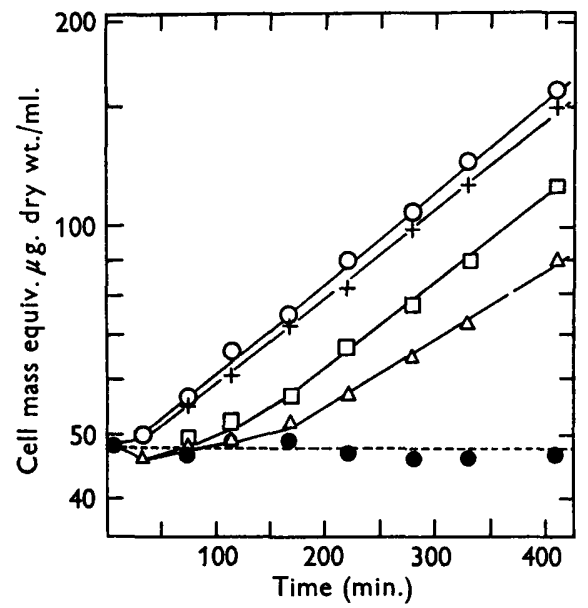

Fig. 1

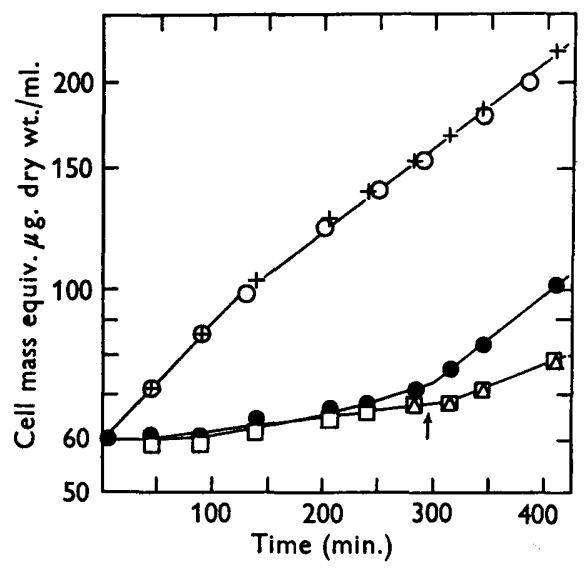

Fig. 2

Fig. 1. Effect of various concentrations of sodium on the growth of Rhodopseudomonas spheroides. The first experimental procedure was used. A portion of an exponentially growing culture was washed twice with medium B with $50 \mu \mathrm{g}$. L-proline/ml. (in place of the glutamic + aspartic acids mixture) and $260 \mu \mathrm{g} . \mathrm{K}^{+} / \mathrm{ml}$. and finally resuspended in $400 \mathrm{ml}$. of the same medium. Eighty ml. of this suspension were placed in each of five growth flasks containing $\mathrm{NaCl}$ to give the final concentrations of $\mathrm{Na}$ shown in the figure. The cultures were aerated with a gas mixture consisting of $95 \%(\mathrm{v} / \mathrm{v})$ nitrogen $+5 \%(\mathrm{v} / \mathrm{v}) \mathrm{CO}_{2} . \mu \mathrm{g} \mathrm{Na}+\mathrm{ml} .: \mathrm{O}_{-} \mathrm{O}, 200 ;+-+, 40 ; \square-\square, 10 ; \Delta-\Delta, 5 ; 0-0,0$.

Fig. 2. Effect of different sodium salts and of other alkali chlorides on the growth of Rhodopseudomonas spheroides. In this experiment the first experimental procedure was used. A portion of an exponentially growing culture was washed twice with medium $B$ with $50 \mu \mathrm{g}$. L-proline $/ \mathrm{ml}$. (in place of the glutamic + aspartic acids mixture) and $260 \mu \mathrm{g}$. $\mathrm{K}+/ \mathrm{ml}$, and finally resuspended in the same medium. Eighty $\mathrm{ml}$. of this suspension were placed in each of six growth flasks and were supplemented as follows: Flask 1 (O-O), $200 \mu$ g. $\mathrm{Na}^{+} / \mathrm{ml}$. (as NaC); flask $2(+-+), 100 \mu \mathrm{g}$. Nat/ml. (as $\mathrm{Na}_{2} \mathrm{SO}_{4}$ ); flask $3(+-+), 100 \mu \mathrm{g}$. $\mathrm{Na}^{+} / \mathrm{ml}$. (as $\mathrm{NaNO}_{3}$ ); flask $4\left(\mathrm{O}_{-}\right), 100 \mu \mathrm{g}$. $\mathrm{Li}^{+} / \mathrm{ml}$. (as $\mathrm{LiCl}$ ); flask $5(\square-\square)$; $100 \mu \mathrm{g} . \mathrm{Rb}^{+} / \mathrm{ml}$. (as RbCl); flask $6(\Delta-\Delta), 100 \mu \mathrm{g} . \mathrm{Cs}^{+} / \mathrm{ml}$. (as $\mathrm{CsCl}$ ). At the time indicated by the arrow, $\mathrm{NaCl}$ was added to flasks $4-6$ to give a final $\mathrm{Na}^{+}$concentration of $100 \mu \mathrm{g} . / \mathrm{ml}$.

Table 3. Ion requirements for the growth of Rhodopseudomonas spheroides: potassium, lithium, rubidium and caesium

The second experimental procedure was used. Medium B, with $50 \mu \mathrm{g}$. $\mathrm{Na}^{+} / \mathrm{ml}$. but without potassium was inoculated with a suspension of twice-washed organisms. Fifteen ml. of inoculated medium were placed in each tube. The final concentration of the cations was $50 \mu \mathrm{g} . / \mathrm{ml}$.; they were added as chlorides. The initial cell-mass was equivalent to $c .12 \mu \mathrm{g}$. dry weight $/ \mathrm{ml}$.

\begin{tabular}{lcc} 
Growth after & $\begin{array}{c}\text { Growth rate } \\
25 \text { hr. } \\
(\mu \mathrm{g} . / \mathrm{ml} .)\end{array}$ & $\begin{array}{c}\text { constant } \\
\left(\mathbf{h r} \mathbf{-}^{-1}\right)\end{array}$ \\
\hline Ion & $\mathbf{2 5}$ & - \\
\hline $\mathrm{Li}^{+}$ & $\mathbf{3 2}$ & $\mathbf{0 . 0 6}$ \\
$\mathbf{K}^{+}$ & 148 & $0 \cdot 14$ \\
$\mathbf{R b}^{+}$ & 144 & $0 \cdot 13$ \\
$\mathbf{C s}^{+}$ & 51 & $0 \cdot 07$
\end{tabular}




\section{Sodium-potassium interaction}

Antagonisms between sodium and potassium ions have been shown to occur in bacteria (MacLeod \& Onofrey, 1956). After it had been found that Rhodopseudomonas spheroides requires both sodium and potassium for growth, it seemed worthwhile to examine the effect of various concentrations of each of these ions on the requirement for the other. Data from a series of experiments showed (Table 4), first that sodium ion, even at high concentrations, did not inhibit the growth of $\boldsymbol{R}$. spheroides. This was true regardless of the ratio of the concentrations of sodium to potassium ion. Secondly, potassium slightly inhibited growth when the ratio of $\mathrm{K}^{+}$to $\mathrm{Na}^{+}$exceeded 5 . The degree of inhibition was more or less independent of the absolute concentrations of the ions. Finally, the results of these experiments showed that the optimum concentrations of the ions were approximately $50 \mu \mathrm{g} . / \mathrm{ml}$. for $\mathrm{Na}^{+}$ and $5 \mu \mathrm{g} . / \mathrm{ml}$. for $\mathrm{K}^{+}$.

The response to very low concentrations of sodium was studied in more detail in a separate experiment (Fig. 3). Extrapolation of the curve to $\mu=0$

Table 4. Ion requirements for growth of Rhodopseudomonas spheroides: sodium-potassium interaction

The second experimental procedure was used; $100 \mathrm{ml}$. portions of medium $B$ with the sodium concentrations shown were inoculated with a suspension of twice-washed organisms, $15 \mathrm{ml}$. portions dispensed into test tubes and $\mathrm{KCl}$ added as required. Initial cell mass was equivalent to $c .8 \mu \mathrm{g}$. dry weight $/ \mathrm{ml}$.

\begin{tabular}{|c|c|c|c|c|c|c|c|}
\hline $\begin{array}{c}\mathbf{N a}^{+} \\
(\mu \mathrm{g} \cdot / \mathrm{ml} .)\end{array}$ & $\begin{array}{c}\mathbf{K}^{+} \\
(\mu \mathrm{g} \cdot / \mathrm{ml} .)\end{array}$ & $\frac{\mathbf{K}^{+}}{\mathbf{N a}^{+}}$ & $\begin{array}{l}\text { Growth } \\
\text { rate } \\
\text { constant } \\
\left(\mathrm{hr} .^{-1}\right)\end{array}$ & $\begin{array}{c}\mathrm{Na}^{+} \\
(\mu \mathrm{g} \cdot / \mathrm{ml} .)\end{array}$ & $\begin{array}{c}\mathbf{K}^{+} \\
(\mu \mathrm{g} \cdot / \mathbf{l} .)\end{array}$ & $\frac{\mathbf{K}^{+}}{\mathbf{N a}^{+}}$ & $\begin{array}{c}\text { Growth } \\
\text { rate } \\
\text { constant } \\
\left(\text { hr. }{ }^{-1}\right)\end{array}$ \\
\hline o & $\begin{array}{r}\mathbf{2 \cdot 5} \\
10 \\
50 \\
100 \\
\mathbf{5 0 0} \\
\mathbf{2 5 0 0}\end{array}$ & $\begin{array}{l}- \\
- \\
- \\
-\end{array}$ & \begin{tabular}{|l|}
0.02 \\
0.02 \\
0.02 \\
0.03 \\
0.02 \\
0.01
\end{tabular} & $\mathbf{5 0}$ & $\begin{array}{r}25 \\
50 \\
125 \\
250 \\
500 \\
1250\end{array}$ & $\begin{array}{l}0 \cdot 5 \\
1 \cdot 0 \\
2 \cdot 5 \\
5 \cdot 0 \\
10 \\
25\end{array}$ & $\begin{array}{l}0 \cdot 15 \\
0 \cdot 15 \\
0 \cdot 15 \\
0 \cdot 15 \\
0 \cdot 14 \\
0 \cdot 125\end{array}$ \\
\hline 5 & $\begin{array}{r}\mathbf{2 \cdot 5} \\
\mathbf{5} \cdot 0 \\
\mathbf{1 2 \cdot 5} \\
\mathbf{2 5} \cdot 0 \\
\mathbf{5 0 \cdot 0} \\
\mathbf{1 2 5}\end{array}$ & $\begin{array}{c}0 \cdot 5 \\
1 \cdot 0 \\
2 \cdot 5 \\
5 \cdot 0 \\
10 \\
25\end{array}$ & \begin{tabular}{|l|}
$0 \cdot 063$ \\
$0 \cdot 063$ \\
$0 \cdot 068$ \\
$0 \cdot 067$ \\
$0 \cdot 064$ \\
$0 \cdot 058$
\end{tabular} & 100 & $\begin{array}{r}\mathbf{5 0} \\
\mathbf{1 0 0} \\
\mathbf{2 5 0} \\
\mathbf{5 0 0} \\
\mathbf{1 0 0 0} \\
\mathbf{2 5 0 0}\end{array}$ & $\begin{array}{l}0 \cdot 5 \\
1 \cdot 0 \\
2 \cdot 5 \\
5 \cdot 0 \\
10 \\
25\end{array}$ & $\begin{array}{c}0 \cdot 175 \\
0 \cdot 175 \\
0 \cdot 175 \\
0 \cdot 175 \\
0 \cdot 155 \\
0 \cdot 130\end{array}$ \\
\hline 10 & $\begin{array}{r}5 \\
10 \\
25 \\
50 \\
100 \\
250\end{array}$ & $\begin{array}{r}0 \cdot 5 \\
1 \cdot 0 \\
2 \cdot 5 \\
5 \cdot 0 \\
10 \\
25\end{array}$ & \begin{tabular}{|l|}
$0 \cdot 10$ \\
$0 \cdot 10$ \\
$0 \cdot 11$ \\
$0 \cdot 11$ \\
$0 \cdot 10$ \\
$0 \cdot 09$
\end{tabular} & 250 & $\begin{array}{r}125 \\
250 \\
625 \\
1250\end{array}$ & $\begin{array}{l}0 \cdot 5 \\
1 \cdot 0 \\
2 \cdot 5 \\
5 \cdot 0\end{array}$ & $\begin{array}{l}0 \cdot 155 \\
0 \cdot 155 \\
0 \cdot 155 \\
0 \cdot 130\end{array}$ \\
\hline 20 & $\begin{array}{r}10 \\
20 \\
50 \\
100 \\
200 \\
500\end{array}$ & $\begin{array}{c}0 \cdot 5 \\
1 \cdot 0 \\
2 \cdot 5 \\
5 \cdot 0 \\
10 \\
25\end{array}$ & $\begin{array}{l}0 \cdot 13 \\
0 \cdot 15 \\
0 \cdot 15 \\
0 \cdot 14 \\
0 \cdot 13 \\
0 \cdot 12\end{array}$ & & & & \\
\hline
\end{tabular}


indicates a contamination of the medium to the extent of about $1 \mu \mathrm{g} . \mathrm{Na}^{+} / \mathrm{ml}$. The minimum contamination calculated from the manufacturers' analyses of the reagents used is about $\mathbf{0 \cdot 2 - 0 \cdot 3} \mu \mathrm{g}$. $\mathrm{Na}^{+} / \mathrm{ml}$. Thus it seems very likely that in the complete absence of sodium the growth rate would be nil.

Ammonium ion has been shown to antagonize potassium (MacLeod \& Snell, 1948). The results of a series of experiments analogous to those just described indicated that sodium was required for normal growth even in the absence of ammonium ion. High concentrations of ammonium ion were inhibitory, to more or less the same extent as potassium.

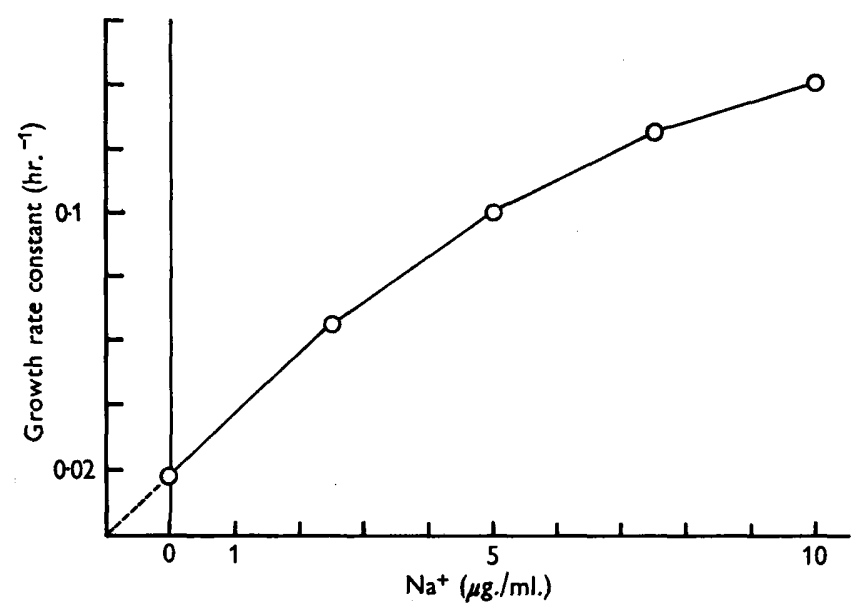

Fig. 3. The effect of low concentrations of sodium on the growth of Rhodopseudomonas spheroides. The first experimental procedure was used. Medium B (100 ml.) with $50 \mu \mathrm{g} . \mathrm{K}^{+} / \mathrm{ml}$. was inoculated with a suspension of twice-washed organisms to an optical density equiv. c. $12 \mu \mathrm{g}$. dry weight/ml. Twenty $\mathrm{ml}$. portions were added to test tubes containing the required amounts of $\mathrm{NaCl}$.

\section{Morphological changes induced by growth in low concentrations of sodium}

Since Rhodopseudomonas spheroides has a very variable morphology, especially under adverse conditions (van Niel, 1944), it seemed likely that organisms growing in suboptimal sodium concentrations would be morphologically abnormal. Examination of smears stained with crystal violet and wet mounts bore out this expectation; many filamentous forms were seen in media with low concentrations of $\mathrm{Na}^{+}$. The filamentous forms reached a maximum length (in medium $\mathrm{B}$ with $5 \mu \mathrm{g}$. $\mathrm{Na}^{+} / \mathrm{ml}$.) after a four- to five-fold increase in optical density; the increase in length was more or less proportional to the increase in optical density and presumably also to protoplasmic growth. The filaments were seen also in a medium with $2.5 \mu \mathrm{g}$. $\mathrm{Na}^{+} / \mathrm{ml}$. The morphology of organisms in a medium with $7.5 \mu \mathrm{g} . \mathrm{Na}+/ \mathrm{ml}$. was almost normal and with $10 \mu \mathrm{g}$. $\mathrm{Na}^{+} / \mathrm{ml}$. it was entirely so. This morphological change is reminiscent of that observed by Webb $(1948,1949)$ in Clostridium welchii during growth in a medium deficient in magnesium; Pappenheimer \& Shaskan (1944) mentioned that this organism became filamentous in an iron-deficient medium. 


\section{DISCUSSION}

With the knowledge that Rhodopseudomonas spheroides requires sodium for growth a truly adequate minimal medium can be formulated. The results presented indicate that medium $\mathbf{A}$, with omission of the amino acids required for rapid growth, is a satisfactory minimal medium. Organisms which require sodium for growth are rare among the non-marine protista and are apparently limited to representatives of the bacteria and blue-green algae. MacLeod (MacLeod et al. 1954) mentioned, without details, that two of the non-marine bacteria examined by him required sodium. The earlier reports of a beneficial effect of sodium on the growth of Bacillus subtilis (Lipman, 1909) and of Escherichia coli (Holm \& Sherman, 1921) are difficult to evaluate because of the complexity of the basal media used. Among the bluegreen algae species of Synechococcus, Chroococcus and Oscillatoria (Allen, 1952) and Anacystis and Anabaena (Kratz \& Myers, 1955) have been shown to require sodium for growth. The same is very probably true of Microcystis aeruginosa (Gerloff, Fitzgerald \& Skoog, 1952). The requirements of Anacystis and Anabaena are met by c. $50 \mu \mathrm{g}$. Na. ${ }^{+} / \mathrm{ml}$, which is very similar to the amount required by $R$. spheroides. It seems probable that all these organisms require only low concentrations of the ion.

The existence of a group of protista distinguished by a requirement for small amounts of sodium does not seem to have been remarked previously, and raises several questions which may be pertinent to the elucidation of the basis of the sodium requirement in marine bacteria: (i) Are there bacteria in the sea which require low concentrations of sodium? (ii) Are there bacteria which require concentrations of sodium intermediate between that required by Rhodopseudomonas spheroides and by marine bacteria? (iii) Is a requirement for sodium more widespread among bacteria than is commonly supposed?

This work was supported in part by a Grant (G 5265) from the National Science Foundation.

\section{REFERENCES}

Allen, M. B. (1952). The cultivation of Myxophyceae. Arch. Mikrobiol. 17, 34 .

Cohen-Bazire, G., Sistrom, W. R. \& Stanier, R. Y. (1957). Kinetic studies of pigment synthesis by non-sulfur purple bacteria. J. cell. comp. Physiol. 49, 25.

Gerloff, G. C., Frtzgerald, G. P. \& Skoog, F. (1952). The minimal nutrition of Microcystis aeruginosa. Amer. J. Bot. 39, 26.

Griffiths, M. \& Stanier, R. Y. (1956). Some mutational changes in the photosynthetic pigment system of Rhodopseudomonas spheroides. J. gen. Microbiol. $14,698$.

Houm, G. E. \& Sherman, J. M. (1921). Salt effects in bacterial growth. I. Preliminary investigation. J. Bact. 6, 511.

HutNer, S. H. (1944). Growth requirements of the photosynthetic bacterium Rhodospirillum rubrum. Arch. Biochem. 3, 439.

KrATz, W. A. \& MYers, J. (1955). Nutrition and growth of several blue-green algae. Amer. J. Bot. 42, 282. 
Lipman, C. B. (1909). Toxic and antagonistic effects of salts as related to ammonification by Bacillus subtilis. Bot. Gaz. 48, 105.

MacLeOd, R. A. \& ONOFrey, E. (1956). Nutrition and metabolism of marine bacteria. II. Observations on the relation of sea-water to the growth of marine bacteria. J. Bact. 71, 661 .

MAcLeOD, R. A. \& ONoFrey, E. (1957). Nutrition and metabolism of marine bacteria. III. Relation of sodium and potassium to growth. J. cell. comp. Physiol. 50,1 .

MacLeod, R. A., ONofrey, E. \& Norris, M. E. (1954). Nutrition and metabolism of marine bacteria. I. Survey of nutritional requirements. J. Bact. 68, 680 .

MacLeOd, R. A. \& SNeld, E. E. (1948). The effect of related ions on the potassium requirement of lactic acid bacteria. J. biol. Chem. 176, 39.

NiEL, C. B. VAN (1944). The culture, general physiology, morphology and classification of the non-sulfur purple and brown bacteria. Bact. Rev. 8,1 .

Pappenheimer, A. M., Jr. \& Shaskan, E. (1944). The effect of iron on carbohydrate metabolism of Clostridium welchii. J. biol. Chem. 155, 265.

Roberts, R. B., Cowie, D. B., Abelson, P. H., Bolten, E. T. \& Briten, R. J. (1957). Studies of biosynthesis in Escherichia coli. Publ. Carneg. Instn, p. 10.

Webs, M. (1948). The influence of magnesium on cell division. 1 . The growth of Clostridium welchii in complex media deficient in magnesium. J. gen. Microbiol. $2,275$.

WEBB, M. (1949). The influence of magnesium on cell division. 2. The effect of magnesium on the growth and cell division of various bacterial species in complex media. J. gen. Microbiol. 3, 410.

(Received 29 December 1959) 